\title{
OÚRICURI
}

\section{BIOMETRY AND NON-DESTRUCTIVE ALLOMETRIC MODEL FOR ESTIMATING BABASSU (Attalea speciosa) FRUIT VOLUME AND DENSITIES}

\author{
Renato Soares VANDERLEI ${ }^{*}$; José Vieira SILVA ${ }^{2}$; Flávia de Barros Prado MOURA ${ }^{2}$ \\ ${ }^{1}$ Mestre; Botany Department, Federal University of Pernambuco. Rua Professor Moraes Rego, Cidade \\ Universitária. 50.670-901. Recife, Pernambuco, Brazil. \\ ${ }^{2}$ Doutor(a), Biological Sciences and Health Institute, Federal University of Alagoas. Paulo Holanda Avenue, \\ 143. 57072-970. Cidade Universitária, Maceió, Alagoas, Brazil. \\ *Corresponding author's email: renato.vanderlei@gmail.com \\ Recebido: 28.07.2019 Aceito: 20.05.2020 \\ http://doi.org/10.29327/ouricuri.9.2-1
}

\begin{abstract}
Biometric data of fruits, such as volume and density, can be applied for different ecological and economic purposes. Non-destructive allometric models based on morphometric dimensions can be more accurate and practical in field conditions than destructive methods used in traditional growth curves. Babassu is a Brazilian native palm tree with wide distribution whose fruits are of high importance for socioeconomic and cultural purposes, in addition to having high potential for biodiesel production. The objectives of this work were to analyse morphometric and biometrically the babassu fruits and create a non-destructive allometric model to estimate their volumes and densities from their dimensions. Weight, polar and longitudinal diameters, volume and density were measured in 156 fruits. The dimensions were applied in the formula to estimate the volume of an ellipsoid object, which matches the shape of the babassu fruit. The non-destructive allometric model was created by calculating a correction factor to adjust the precision of the formula. Our model improved the accuracy of volumes and densities calculated by $24 \%$. Strong correlations were also found between the morphometric and biometric parameters. Therefore, this allometric model can be used to assist in selecting the most suitable fruits to improve economic, propagation and conservation studies.
\end{abstract}

Keywords: Allometry; Fruit Shape; Ellipsoid Fruits.

\section{BIOMETRIA E MODELO ALOMÉTRICO NÃO-DESTRUTIVO PARA ESTIMAR VOLUME E DENSIDADES DE FRUTOS DE BABAÇU (Attalea speciosa)}

Resumo: Dados biométricos de frutos, como volume e densidade, podem ser aplicados em diferentes propósitos ecológicos e econômicos. Modelos alométricos não-destrutivos a partir de dimensões morfométricas podem ser mais precisos e práticos em condições de campo que estimativas destrutivas e curvas de crescimento tradicionais para estimar estes parâmetros. $O$ babaçu é uma palmeira nativa do Brasil com ampla distribuição cujo frutos são de alta importância para fins socioeconômicos e culturais, além de possuírem alto potencial para produção de biodiesel. Os objetivos deste trabalho foram analisar morfométrica e biometricamente os frutos de babaçu e criar um modelo alométrico não-destrutivo para estimar seus volumes e densidades a partir das suas dimensões. O peso, diâmetros polar e longitudinal, volume e densidade foram medidos em 156 frutos. As dimensões foram aplicadas na fórmula para estimar o volume de um objeto elipsoide, que coincide com a forma do fruto do babaçu. O modelo alométrico não-destrutivo foi criado pelo cálculo de um fator de correção para ajustar a precisão da fórmula. Nosso modelo melhorou a precisão dos volumes e densidades calculados em $24 \%$. Correlações fortes também foram encontradas entre os parâmetros morfométricos e biométricos. Portanto, este modelo alométrico 
pode ser usado para auxiliar na seleção de frutos mais adequados para melhorar os estudos econômicos, de propagação e conservação.

Palavras-chave: Alometria; Formato do Fruto; Frutos Elipsoides.

\section{BIOMETRÍA Y MODELO ALOMÉTRICO NO DESTRUCTIVO PARA ESTIMAR LOS VOLUMENES Y DENSIDADES DE FRUTAS DE BABAÇU (Attalea speciosa)}

Resumen: Los datos biométricos de las frutas, como el volumen y la densidad, se pueden aplicar para diferentes propósitos ecológicos y económicos. Los modelos alométricos no destructivos basados en dimensiones morfométricas pueden ser más precisos y prácticos en condiciones de campo que los métodos destructivos utilizados en las curvas de crecimiento tradicionales. Babassu es una palmera nativa brasileña con una amplia distribución cuyos frutos son de gran importancia para fines socioeconómicos y culturales, además de tener un alto potencial para la producción de biodiesel. Los objetivos de este trabajo fueron analizar morfométrica y biométricamente los frutos de babasú y crear un modelo alométrico no destructivo para estimar sus volúmenes y densidades a partir de sus dimensiones. El peso, los diámetros polares y longitudinales, el volumen y la densidad se midieron en 156 frutos. Las dimensiones se aplicaron en la fórmula para estimar el volumen de un objeto elipsoide, que coincide con la forma del fruto de babasú. El modelo alométrico no destructivo se creó calculando un factor de corrección para ajustar la precisión de la fórmula. Nuestro modelo mejoró la precisión de los volúmenes y las densidades calculadas en un $24 \%$. También se encontraron fuertes correlaciones entre los parámetros morfométricos y biométricos. Por lo tanto, este modelo alométrico se puede utilizar para ayudar a seleccionar las frutas más adecuadas para mejorar los estudios económicos, de propagación y conservación.

Palabras clave: Alometría; Forma de Fruta; Frutas Elipsoidales.

\section{INTRODUCTION}

Biometric fruit data are important variables that reflect nutritional and ecological information, such as increased nutrients and germination (Martínez et al., 2007), and therefore can be applied in physiological, functional, production and recruitment of seedlings and biofuels studies (Martínez et al., 2007; Omid et al., 2010; Pérez-Harguindeguy et al., 2013; Protásio et al., 2017).

In fruits, morphometric measurements such as size, weight, volume and density are somewhat correlated. Bigger fruits generally possess bigger seeds, which indicate more nutritional content and result in enhanced germination (Zimmerman and Weis, 1983), and fruit size also influence fruit sale value (Hall et al., 1996). Fruit volume and density relate with fruit consistency, flavour, carbon consumption (Machado and Almeida, 1989) and can be used for predicting harvesting periods (Hahn; Sanchez, 2000). In order to estimate these variables, growth curves are performed using decoupled samples (i.e. destructive method) which may lead to erroneous results. In this sense, the fruit diameters and widths can be used to generate allometric models and estimate fruit these variables producing more accurate results (Godoy et al., 2008; Jorquera-Fontena et al., 2017).

The babassu (Attalea speciosa Mart. ex Spreng) (Arecaceae) is a palm tree endemic to Brazil with a wide geographic distribution, occurring in four of the five regions of the country (Leitman et 
al., 2014). This species has substantial socioeconomic importance due to the use of its different parts by traditional communities to generate income (e.g. leaves and stem are destined for handicraft and heart of palm extraction (Campos et al., 2015).

The most recent available data estimates that, in 2018, the babassu market was responsible for the largest share of income generation among the oilseed species, generating more than 90 million reais (IBGE, 2020). The components of the fruit may be used for different products: (a) the epicarp can be used for charcoal, plant pots, containers and organic fertilizer; (b) the mesocarp, rich in starch, can be used for charcoal and flour production, which is used for human food; (c) the endocarp is used by pharmaceutical, chemical and food industries and also for charcoal and handicrafts production; (d) the almonds are used for oil extraction, more than $60 \%$ of them are composed of oil rich in lauric acid $\left(\mathrm{C}_{12} \mathrm{H}_{24} \mathrm{O}_{2}\right)$ (Carrazza et al., 2012; Campos et al., 2015).

Biometric data of fruits such as volume and density are directly influenced by their size and used for yield prediction, crop management, seedlings and as source of bioenergy (Protásio et al., 2014; Tijskens et al., 2016). Bigger fruits are more likely to proportionally have more biomass in their compartments (i.e. epicarp, mesocarp and endocarp), and a higher amount or larger seeds, which can make them more suitable for biofuel production, and their biometric data work as good indicators. Fruit volumes can be determined by using the water displacement technique, however this method is not only destructive, time consuming and impractical to be used under field conditions (Bozokalfa and Kilic, 2010).

In the case of babassu fruits, volume and density measurements reflect the biomass allocation, its potential for coal production (Protásio et al., 2014) and extraction of high quality oil (Bouaid et al., 2015). By estimating these variables without decoupling the fruit, it is possible to choose the which ones are more likely to present increased germination rates, bigger seeds and, consequently, nutritional content. Considering the millions of hectares of tropical forests with a great amount of babassu palm trees and the possibilities of the integral use of the coconut, combined with its oil and physical properties (Lima et al., 2007; Protásio et al., 2017), babassu fruits potentially constitute extraordinary raw material to be used a feasible alternative energy source.

Therefore, given the social and economic importance of this species, the aims of this study were to measure the biometric variables of the babassu fruits and to create a non-destructive allometric model for estimating the fruits' volume and density based on an ellipsoid shape.

\section{MATERIALS AND METHODS}

\section{Data collection area}

The fruits $(n=156)$ were collected from a mature bunch of a tree, after the flowering period, located in the Vale do Catimbau, State of Pernambuco, northeast of Brazil (8॰34'15.0"S $\left.37^{\circ} 14^{\prime} 50.8^{\prime \prime} \mathrm{W}\right)$. The mean annual temperature and rainfall are respectively $600 \mathrm{~mm}$ and $26^{\circ} \mathrm{C}$, most 
rain is recorded between April and June. All the fruits from the bunch were measured, capturing their natural size variation, and analyzed in the Laboratory of Tropical Plants, located at the Federal University of Alagoas, Campus A.C. Simões.

\section{Morphometric, biometric measurements and allometric model}

The following parameters of the fruits were measured: weight, volume, density, polar and longitudinal diameters. Each fruit was weighed on an analytical scale (precision, $0.01 \mathrm{~g}$ ) and the dimensions were taken using a digital caliper $(0.01 \mathrm{~mm})$.

Three different categories of fruit volumes and densities were measured and compared (Real, Calculated and Adjusted) to generate the non-destructive mathematical allometric model based on the formula to calculate the volume of an ellipsoid-shaped object using the $R$ software ( $R$ Development Core Team 2016). Real volume $\left(R_{\text {vol }}\right)$ was measured by the water displacement method (Archimedes' Principle). Real density $\left(R_{d e n}\right)$ was calculated by dividing the weight of the fruits (g) by its real volumes (cm3).

The calculated volume $\left(C_{v o l}\right)$ was measured using the equation to estimate the volume of an ellipsoid object (equation 1): Volume $=\left(\frac{4}{3} \pi\right) \times a \times b \times c$. Where $\mathrm{a}, \mathrm{b}$ and $\mathrm{c}$ are respectively the longest and shortest polar diameters and the longitudinal diameter of the fruit (Olver et al., 2010). The equation had to be adjusted twice. The first adjustment was on the values of the formula: mathematically, as a, b and c represent semi-axis of the ellipse (i.e. half of the complete axis), each one must be divided by 2 .

The second adjustment was on the diameter's measurements, once, according to the volume equation, when the fruit is pill shaped (i.e. oblate ellipsoid) (Figure 1) "a" equals "b". Therefore, the final equation to calculate the volume was (equation 2): $C_{v o l}=0.5236 \times a^{2} \times c$. Calculated density $\left(\mathrm{C}_{d e n}\right)$ was then determined by dividing the weight of each fruit by its respective calculated volumes.

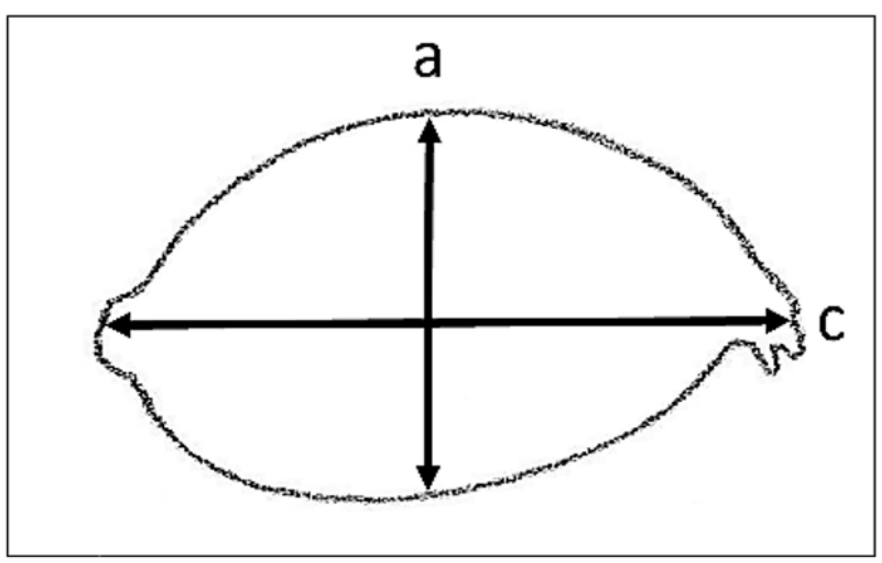

Figure 1. Babassu fruit's shape. Polar and longitudinal diameters represented by 'a' and 'c' respectively. 
The Adjusted volume $\left(A_{v o l}\right)$ was calculated by multiplying the Calculated volumes by an average correction factor ( $\mathrm{cf}_{\text {vol }}$ ) obtained by dividing the Real volumes by the Calculated volumes, aiming to enhance the accuracy and reduce the error between both variables. Then, the $A_{\text {vol }}$ was used to calculate de Adjusted density $\left(A_{d e n}\right)$ by dividing the weight of each fruit by its respective adjusted volumes.

Linear regression analyses were performed between the variables to calculate possible correlations. The data of volumes and densities were analyzed by ANOVA, while means were compared by Tukey test with 5\% significance level. The data tested for normality with the ShapiroWilk test and for homogeneity of variance with the Levene test; non-normal data were logtransformed. All the analyses were performed using the software R 3.5.2 ( $R$ Development Core Team, 2019).

\section{RESULTS}

The weight, polar and longitudinal diameters values varied between 44.5 to $133.5 \mathrm{~g} ; 36.7$ to $57.77 \mathrm{~mm}$, and 63.74 to $88.69 \mathrm{~mm}$, respectively. The real, calculated and adjusted volumes $\left(\mathrm{F}_{2.465}=\right.$ 97.8, $p<0.0001)$ and densities $\left(F_{2.465}=526.3, p<0.0001\right)$ values were different from each other. No differences between the real and adjusted volumes and densities were found, whereas the calculates values were different from both groups $(p<0.0001)($ Table 1$)$.

Table 1. Morphometric and biometric measures of babassu fruits.

\begin{tabular}{|c|c|c|c|c|}
\hline Variable & Average & Minimum & Maximum & $\begin{array}{l}\text { Coefficient of } \\
\text { variation }(\%)\end{array}$ \\
\hline
\end{tabular}

\begin{tabular}{|c|c|c|c|c|}
\hline \multicolumn{5}{|l|}{ Fruits } \\
\hline Weight (g) & $88.35( \pm 18.852)$ & 44.50 & 133.50 & 21.337 \\
\hline Polar diameter (mm) & $49.79( \pm 4.128)$ & 36.70 & 57.77 & 8.291 \\
\hline Longitudinal diameter (mm) & $77.85( \pm 4.458)$ & 63.74 & 88.69 & 5.727 \\
\hline \multicolumn{5}{|l|}{ Volume } \\
\hline Real volume $\left(\mathrm{cm}^{3}\right)$ & $78.108( \pm 17.406) \mathrm{a}$ & 32.000 & 116.300 & 22.284 \\
\hline Calculated volume $\left(\mathrm{cm}^{3}\right)$ & $102.353( \pm 20.232) b$ & 51.538 & 144.933 & 19.767 \\
\hline Adjusted volume $\left(\mathrm{cm}^{3}\right)$ & $77.816( \pm 15.382) \mathrm{a}$ & 39.183 & 110.188 & 19.767 \\
\hline \multicolumn{5}{|l|}{ Density } \\
\hline Real density $\left(\mathrm{g} / \mathrm{cm}^{3}\right)$ & $1.139( \pm 0.099) \mathrm{A}$ & 0.863 & 1.528 & 8.678 \\
\hline Calculated density $\left(\mathrm{g} / \mathrm{cm}^{3}\right)$ & $0.864( \pm 0.068) \mathrm{B}$ & 0.642 & 1.205 & 7.828 \\
\hline Adjusted density $\left(\mathrm{g} / \mathrm{cm}^{3}\right)$ & $1.136( \pm 0.089) \mathrm{A}$ & 0.845 & 1.584 & 7.828 \\
\hline
\end{tabular}


Strong positive correlations were found when compared the Adjusted volume to the following variables: weight $\left(r^{2}=88\right)$, polar diameter $\left(r^{2}=0.86\right)$ and longitudinal diameter $\left(r^{2}=0.82\right)$; also, weight and polar diameter $\left(r^{2}=0.84\right)$ (Figure 2a-2d). The positive strong correlations found between the volume and morphological dimensions of the fruits corroborate the accuracy of using morphometric measures to estimate the biometric parameters of the model.
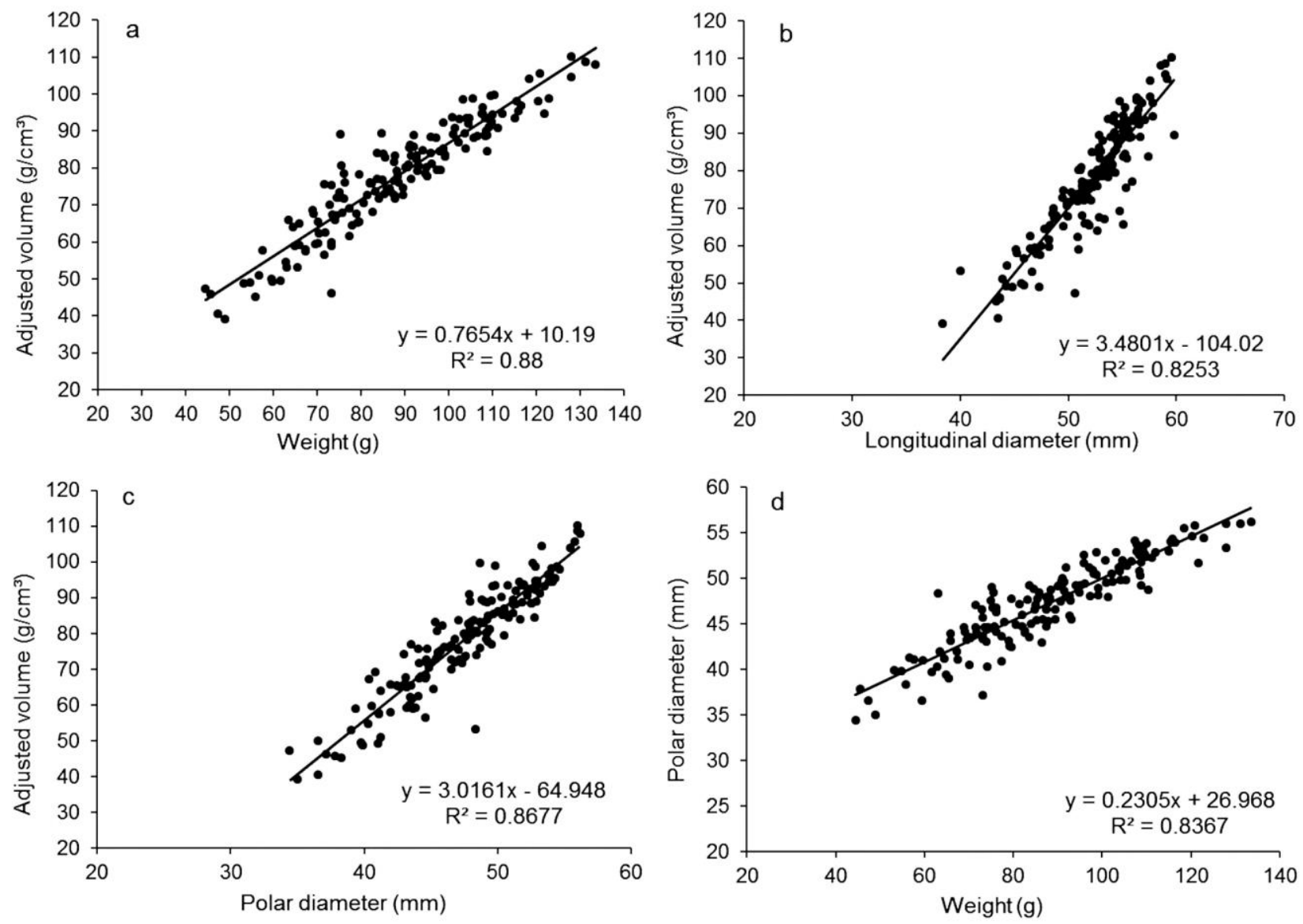

Figure 2. Relationships between the adjusted volumes $\left(A_{v o l}\right)$ and (a) weight; (b) and longitudinal diameter; (c) and polar diameter; (d) weight and polar diameter.

The value found for the volume correction factor was $c f_{v o l}=0.7602709( \pm 0.053)$. The average real volume differed from the calculated volume by $24 \%$, whereas the average difference between the real and adjusted volumes was $0.29 \%$. Moreover, the difference between the Real and Calculated densities was $24 \%$, whereas between Real and Adjusted densities was $0.17 \%$ (Figure $3)$. 
A

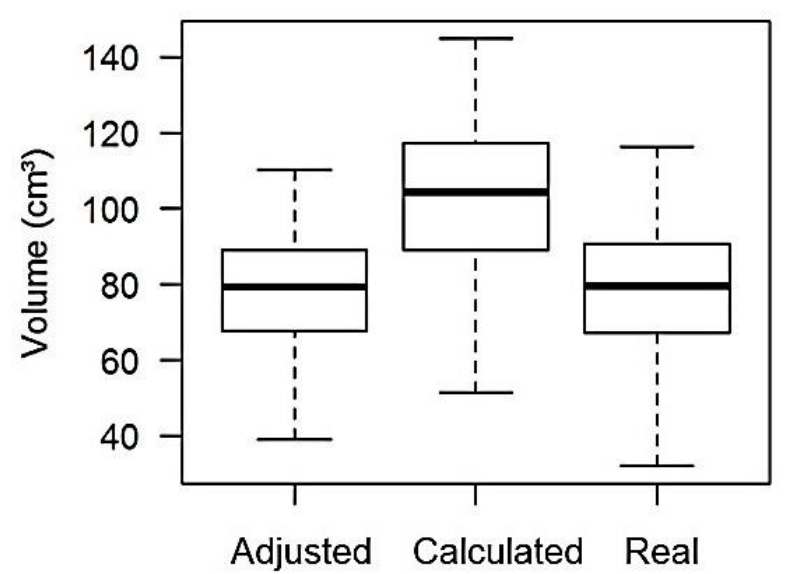

Categories
B

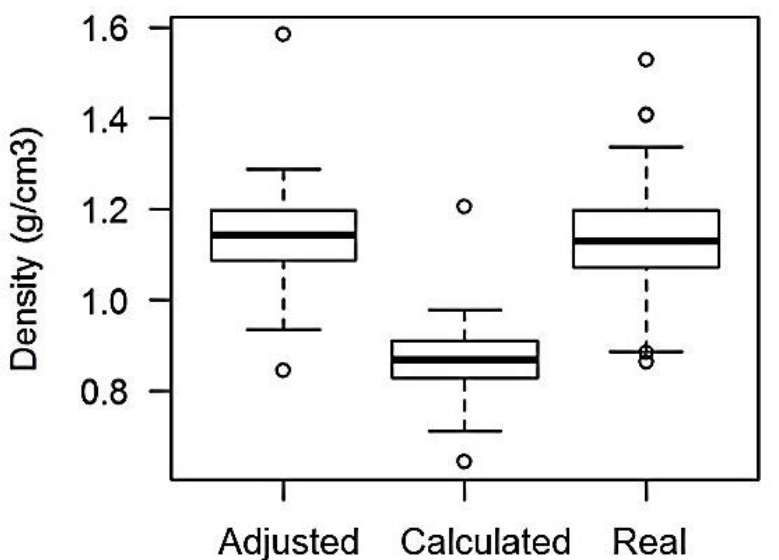

Categories

Figure 3. Data distribution among the categories of the volumes (A) and densities (B).

The final non-destructive allometric model to adjust the calculated volumes is (equation 3)

$$
A_{v o l}=\left(\left(\frac{4}{3} \pi\right) \times a^{2} \times c\right) \times c f_{v o l}
$$

where $A_{\text {vol }}=$ adjusted volume; $a=$ polar diameter $(\mathrm{mm}) ; c=$ longitudinal diameter $(\mathrm{mm}), c f_{\text {vol }}=$ volume correction factor. Then, once the weight of the fruit is known, one can estimate its density by dividing the weight by the adjusted volume $\left(A_{\text {vol }}\right)$.

\section{DISCUSSION}

Our results suggest that estimating the volume just by using the ellipsoid equation did not present enough accuracy. However, by adapting the equation to the shape of the babassu fruits and applying the calculated correction factor ( $c f_{v o l}$ ), it was possible to substantially improve the accuracy of the calculated volumes and, consequently, by using the adjusted volumes, enhance the accuracy of the calculated densities. The fact that differences were only observed when comparing the values obtained by the regular formula of an ellipsoid object to the real and adjusted values validates the accuracy of the generated allometric model.

There are few studies analyzing morphometric and biometric figures of $A$. speciosa fruits. The mean numbers for the parameters found in this study were lower than the ones reported in the literature for the A. speciosa (Mitja et al., 2008; Carrazza et al., 2012). However, it is important to emphasize that the standard deviation of the diameters found by Mitja et al (2008) and the ones found in this study are similar, indicating that the diameters change proportionally despite the size difference. The mean weight of the fruits also followed the positive trend regarding bigger fruits; thus, a similar response would be expected for the strong correlations we observed among the variables. 
The variability in morphometric and biometric parameters may be influenced by several aspects: Santos et. al. (2016) reported significant variability in fruit weight for different ecological regions, even though no difference was observed for size, meanwhile the volume of fruits can change according to the time of harvesting along the seasons (Hall et al., 1996). Other factors may also exert influence in these parameters, such as the age of the palm tree and fruits, local environmental conditions, water availability, nutritional deficit of the soil, or genetic variability (Ciconini et al., 2013; Santos et al., 2016). In this sense, this variation increments the available information on the natural variety of the fruits' characteristics for this species.

The volume and density of fruits are important trait for several areas of interest and can be measured by different techniques which are time-consuming, destructive and less accurate (Radovich and Kleinhenz, 2004). Therefore, creating a precise non-destructive allometric model to be applied on ellipsoid-shaped fruits is an extremely feasible and practical method, especially under field conditions, once the model we propose only demands the use of a caliper and a regular calculator. This is particularly true regarding the $A$. speciosa species, once it fruits are responsible for a representative source of income for local population across Brazil which depend on oilseed exploitation and use (Carrazza et al., 2012). Moreover, due to the potential use of this species as an alternative bioenergy source (i.e. coal and biofuel production), facilitating the estimation of these variables is an important step to select appropriate fruits for further economic and environmental studies related to propagation, dispersal, germination, conservation and management of the species. Therefore, the analyzed data may benefit further investigations related not only to $A$. speciosa but also other species presenting ellipsoid-shaped fruits.

\section{CONCLUSION}

Mathematical formulas to estimate the volume of fruits require specific corrections regarding the shape of the fruits before being applied in order to enhance their results.

The allometric model obtained is presented as a fast, inexpensive and effective way to facilitate the estimation of volume and density of babassu fruits in conditions of low availability of resources or in the field.

\section{REFERENCES}

Bouaid, A.; El Boulifi N.; Martínez, M.; Aracil, J. Biodiesel Production from Babassu Oil: A Statistical Approach. Journal of Chemical Engineering \& Process Technology, 6(3), 1-4, 2015. DOI 10.4172/2157-7048.1000232.

Bozokalfa, K.; Kilic, M. Mathematical modeling in the estimation of pepper (Capsicum annuum L.) fruit volume. Chilean Journal of Agricultural Research, 40(5), 626-632, 2010.

Campos, J. L. A.; Silva, T. L. L.; Albuquerque, U. P.; Peroni, N.; Araújo, E. A. Knowledge, Use, and Management of the Babassu Palm (Attalea speciosa Mart. ex Spreng) in the Araripe Region 
(Northeastern Brazil). Economic Botany, 69(3), 240-250, 2015. DOI 10.1007/s12231-015-9315-x.

Carrazza, L. R.; Ávila, J. C. C.; Sllva, M. L. Manual tecnológico: Aproveitamento integral do fruto e da folha do babaçu. Brasília/DF: Instituto Sociedade, População e Natureza (ISPN), 2012.

Ciconini, G.; Favaro, S. P.; Roscoe, R.; Miranda, C. H. B.; Tapeti, C. F.; Miyahira, M. A .M.; Bearari, L.; Galvani, F.; Borsato, A. V.; Colnago, L. A.; Naka, M. H. Biometry and oil contents of Acrocomia aculeata fruits from the Cerrados and Pantanal biomes in Mato Grosso do Sul, Brazil. Industrial Crops and Products, 45, 208-214, 2013. DOI 10.1016/j.indcrop.2012.12.008.

Godoy, C.; Monterubbianesi, G.; Tognetti, J. Analysis of highbush blueberry (Vaccinium corymbosum L.) fruit growth with exponential mixed models. Scientia Horticulturae, 115(4), 368-376, 2008. https://doi.org/10.1016/j.scienta.2007.10.018.

Hahn, F.; Sanchez, S. Carrot volume evaluation using imaging algorithms. Journal of Agricultural and Engineering Research, 75(3), 243-249, 2000. https://doi.org/10.1006/jaer.1999.0466.

Hall, A. J.; Mcpherson, H. G.; Crawford, R. A.; Seager, N. G. Using early-season measurements to estimate fruit volume at harvest in kiwifruit. New Zealand Journal of Crop and Horticultural Science, 24(4), 379-391, 1996. https://doi.org/10.1080/01140671.1996.9513975.

IBGE. Produção da Extração Vegetal e da Silvicultura. 2020. Available at: https://sidra.ibge.gov.br/tabela/289. Acesso em: 06 de mai. 2020.

Jorquera-Fontena, E.; Génard, M.; Ribera-Fonseca, A.; Franck, N. A simple allometric model for estimating blueberry fruit weight from diameter measurements. Scientia Horticulturae, 219, 131134, 2017. DOI 10.1016/j.scienta.2017.03.009.

Leitman, P.; Soares, K.; Henderson, A.; Noblick, L.; Martins, R.C. Arecaceae in Lista de Espécies da Flora do Brasil. Jardim Botânico do Rio de Janeiro, 2014. Disponível em: <http://floradobrasil.jbrj.gov.br/jabot/floradobrasil/FB15686>.

Lima, J. R.; Silva, R. B.; Silva, C. C.; Santos, L.; Moura, E.; Moura, V. Biodiesel de babaçu (Orbignya sp.) obtido por via etanólica. Química Nova, 30(3), 600-603, 2007.

Machado, R.C.R.; Almeida, H.A. Estimativa do volume do fruto de cacau. Revista Brasileira de Fisiologia Vegetal, 1(1), 115-117, 1989.

Martínez, I.; García, D.; Obeso, J. R. Allometric allocation in fruit and seed packaging conditions the conflict among selective pressures on seed size. Evolutionary Ecology, 21, 517-533, 2007.

Mitja, D.; SILVA, J. C. S.; Melo, S. L.; Filho, H. C. Biometria dos frutos e sementes de babaçu, Natividade - TO. In: IX Simpósio Nacional Cerrado, II Simpósio Internacional de Savanas Tropicais, 2008. p. 8.

Olver, F. W. J.; Lozier, D. W.; Boisvert, R. F.; Clark, C. W. NIST Handbook of Mathematical Functions. Cambridge: Cambridge University Press, 2010.

Omid, M.; Khojastehnazhand, M.; Tabatabaeefar, A. Estimating volume and mass of citrus fruits by image processing technique. Journal of Food Engineering, 100 (2), 315-321, 2010. DOI 10.1016/j.jfoodeng.2010.04.015.

Pérez-Harguindeguy, N.; Diaz, S.; Garnier, E.; Lavorel, S.; Poorter, H.; Jaureguiberry, P.; Bret-Harte, M. S. S.; Cornwell, W. K. K.; Craine, J. M. M.; Gurvich, D. E. E.; Urcelay, C.; Veneklaas, E. J. J.; Reich, P. B. B.; Poorter, L.; Wright, I. J. J.; Ray, P.; Cornelissen, J. H. C. New Handbook for standardized measurment of plant functional traits worldwide. Australian Journal of Botany, 61 (34), 167-234, 2013. DOI http://dx.doi.org/10.1071/BT12225. 
Protásio, T. P.; Truguilho, P. F.; César, A. A. S.; Napoli, A.; Melo, I. C. N. A.; Silva, M. G. S. Babassu nut residues: potential for bioenergy use in the North and Northeast of Brazil. SpringerPlus, 3(124), 1-14, 2014. DOI 10.1186/2193-1801-3-124.

Protásio, T. P.; Guimarães Junior, M.; Mirmehdi, S.; Trugilho, P.F.; Napoli, A.; Knovack, K.M. Combustion of Biomass and Charcoal Made From Babassu Nutshell. Cerne, 23(1), 1-10, 2017. DOI 10.1590/01047760201723012202.

Radovich, T. J. K.; Kleinhenz, M. D. Rapid Estimation of Cabbage Head Volume across a population Varying in Head Shape: A Test of Two Geometric Formulae. HortTechnology, 14 (3), 3-6, 2004.

Santos, D. S.; Silva, I. G.; Barbosa, M. C. L.; Nascimento, M. D. S. B.; Costa, M. C. P. Parâmetros de qualidade físico-química de óleos e análise morfométrica de frutos e sementes da espécie Orbignya phalerata Martius por região ecológica. Eclética Química Journal, 41(1), 74-84, 2016.

R Development Core Team. R: Language and Environment for Statistical Computing. Vienna, Austria, 2019. Available at: http://www.r-project.org/index.html.

Tijskens, L. M. M.; Unuk, T.; Okello, R. C. O.; Wubs, A. M.; Šuštar, V.; Šumak, D.; Schouten, R. E. From fruitlet to harvest: Modelling and predicting size and its distributions for tomato, apple and pepper fruit. Scientia Horticulturae, 204, 54-64, 2016. https://doi.org/10.1016/j.scienta.2016.03.036.

Zimmerman, J. K.; Weis, I. M. Fruit size variation and its effects on germination and seedling growth in Xanthium strumarium (Ontario). Canadian Journal of Botany, 61(9), 2309-2315, 1983. https://doi.org/10.1139/b83-253. 